\title{
PISA 2018'de Okuduğunu Anlama Başarısını Yordayan Değişkenlerin Veri Madenciliği İle Belirlenmesi ${ }^{a}$
}

\author{
Yusuf Kasap b, c, Nuri Doğand, Cem Koçak
}

Özet

Anahtar Kelimeler

Bu araştırmada 2018 yılında PISA'ya katılan öğrencilere sınavla verilen öğrenci anketinden elde edilen 34 bağımsız değişken ile, okuduğunu anlama başarısını yordayabilen önemli değişkenleri belirleme amaçlanmıştır. Bu amaç için PISA'ya katılan 79 ülke başarı yüzdelik sırasına konuldu. Ardından eşit dilimlerle ülkeler alt orta ve üst dilimler olarak ayrıldı. Yüzdelik dilimlerine göre Türkiye dahil 9 ülke seçilerek çalışma örneklemi oluşturulmuştur. Türkiye, alt, orta, üst başarı grubu ve çalışma örneklemi verileri kullanılarak lojistik model ile yapılan analizlerde okuduğunu anlama başarısını yordayan önemli değişkenler, 5-8 arasında değişmiştir. Elde edilen sonuçlara göre başarıyı yordama da Türkiye, alt, orta, üst başarı grubu ülkeler ve çalışma örneklemi için, önemli ortak yordayıcıların; PISA testinin zorluk algisı, ebeveynlerin en yüksek eğitim düzeyi indeksi ve evdeki eğitimsel eşyalar olduğu belirlenmiştir. Daha sonra, önemli değişkenlerle başarıyı sınıflama, çapraz geçerlik ve tahmin performansları hesaplanmıştır. Önemli değişkenlerle yapılan kestirimlerle 34 değişkenle elde edilen modellerdeki performanslara yakın sonuçlar elde edildiği görülmüştür.

\author{
Okuduğunu anlama \\ Veri madenciliği \\ Siniflama \\ Tahmin \\ PISA
}

Makale Hakkında

Geliş Tarihi: 29.06.2021

Kabul Tarihi: 15.12.2021

Doi:10.18026/cbayarsos.959609

\section{Determining Variables That Predict Reading Comprehension Success by Data Mining in PISA 2018}

\begin{abstract}
In this study, it was aimed to determine the important variables that can predict the success of reading comprehension with 34 independent variables obtained from the student questionnaire given to the students who participated in PISA in 2018. For this purpose, 79 countries participating in PISA were put in order of success percentage. Then, with equal slices, countries were divided into lower, middle and upper slices. The study sample was created by selecting 9 countries including Turkey according to their percentiles. In the analyzes made with the logistic model using Turkey, low, medium, high achievement group and study sample data, the important variables predicting reading comprehension success varied between 5 and 8. According to the results obtained, for Turkey, low, middle and high achievement group countries and study sample, it is determined that the important common predictors of success are, the difficulty perception of the PISA test, the highest education level index of the parents and the educational items in the house. Then, classification, cross-validation and prediction performances of success with important variables were calculated. It has been observed that with the estimations made with important variables, results were close to the performances of the models obtained with 34 variables.
\end{abstract}

Keywords

\footnotetext{
a Çalışma "PISA 2018'de Okuduğunu Anlama Başarısını Yordayan Değişkenlerin Veri Madenciliği İle Belirlenmesi” adlı tezin bir parçasıdır.

b Yusufkasap5806@hotmail.com

c Öğrenci, Hacettepe Üniversitesi, yusufkasap5806@hotmail.com, ORCID: 0000000251141175

d Prof. Dr., Hacettepe Üniversitesi Ölçme ve Değerlendirme ABD., nuridogan2004@gmail.com, ORCID: 0000000162742016

e Prof. Dr., Hitit Üniversitesi iktisadi bilimler fakültesi., İktisat Bölümü., cemkocak@hotmail.com, ORCID: 0000000273397438
}

\author{
Reading comprehension \\ Data mining \\ Classification \\ Estimation \\ PISA
}

About Article

Received: 29.06 .2021

Accepted: 15.12 .2021

Doi:10.18026/cbayarsos.959609 


\section{Giriş}

Araştırmalarda bireylerden elde edilen büyük miktarda ham veri ile bireylerin bazı özelliklerini tahmin etme işlemi veri madenciliği (VM) yöntemleri ile yapılabilmektedir. Veri madenciliği yöntemleri; eğitim, pazarlama, genetik, biyoloji, bankacılık, sigortacılık, borsa, perakendecilik, telekomünikasyon, sağlık, ,kriminoloji, endüstri, istihbarat gibi birçok alanda kullanılmaktadır (İnan, 2003; Albayrak, 2009; Akgöbek ve Çakır, 2009).

Eğitimde de son yıllarda hem uluslararası düzeyde hem de ulusal düzeyde yapılan çalışmalarda çok değişkenli veri toplama eğilimi yaygınlaşmıştır. Bu sınavlardan birisi de Uluslararası Öğrenci Değerlendirme Programıdır (PISA). PISA verileri kullanılarak, çok değişkenli VM modelleri ile, başarıyı yordayan veya başarı ile ilişkili bağımsız değişkenlerin hangileri olduğu saptanabilmektedir.

PISA her 3 yılda bir yapılan, Matematik okuryazarlığı, Fen okur yazarlığı ve okuduğunu anlama testlerini içeren bir uygulamadır. Her bir PISA uygulamasında, bu üç testten birine ağırlık verilmektedir. PISA 2018'de ağırlık verilen başlıca alan okuduğunu anlamadır. Bu uygulamada temel amaçlar; metinleri anlama, kullanma, değerlendirme, metinler üzerinde düşünme ve metinlerle etkileşim kurma becerilerini ölçmek olarak belirlenmiştir (OECD, 2019). PISA 2018 uygulaması, 79 ülkenin çoğunluğunda bilgisayar üzerinden dijital olarak gerçekleştirilmiştir.

Alanyazında, akademik başarıyı yordamaya yönelik, veri madenciliği yöntemlerinin kullanıldığı ulusal ve uluslararası bir çok çalışma mevcuttur (Abad ve Lopez, 2016; Abad ve ark., 2020; Abdous ve ark., 2012; Aksoy, 2014; Özarslan, 2014; Pennell ve DiGangi, 2012; Yung ve ark.,2012). Bu çalışmalardan Pennell ve DiGangi (2012) ve Abad ve ark. (2020) çalışmaları, PISA başarı düzeyini yordamaya yöneliktir. Bununla birlikte, alanyazında, başarıyı yordayan faktörlerin belirlenmesine yönelik çalışmalar iki grupta sınıflanabilir. Birinci gruptaki çalışmalar, uygulamalı istatistikteki, $\mathrm{t}$ testi, Mann-Whitney $\mathrm{U}$ testi, ANOVA, Kruskal-Wallis testi, Faktör analizi ve Çoklu regresyon analizi gibi teknikleri kullanan başarıyı yordayan değişkenleri belirlemeye yönelik çalışmalardır (Akkurt ve Köse 2019; Berberoğlu ve ark.,2017; Coşkuner, 2013; Güzle Kayır, 2012; Önder ve Gelbal, 2016; Özkan ve Güvendir, 2014; Uyulgan ve Akkuzu, 2017;Urfalı Dadandı ve ark., 2018; Yıldırım, 2012;). İncelenen çalışmalardan Uyulgan ve Akkuzu (2017) ile Akkurt ve Köse (2019) çalışmalarında PISA verilerini kullanmamıştır. Sonuç olarak PISA başarı puanını yordayan faktörlerin belirlenmesinde uygulamalı istatistiksel yöntemlerin sıklıkla kullanıldığı ve önemli değişkenlerin bu istatistiksel yöntemlerin çıtıları özellikle de p olasılıkları incelenerek belirlendiği söylenebilir.

İkinci gruptaki çalışmalar ise; VM yöntemlerini kullanarak başarıyı yordayan veya başarıyla ilişkili olan değişkenlerin belirlenmesine yönelik olup, bu çalışmaların bazıları PISA başarı düzeyini yordayan değişkenleri tespit etmeye yöneliktir (Abad ve Lopez, 2016; Aksu, 2016; Gamazo ve Abad, 2020; Kıray ve ark., 2015; Yu ve ark., 2012). Örneğin; Abad ve Lopez (2016) çalışmasında, akademik başarıyı yordayan faktörleri belirlemek için C4.5 karar ağacı sınıflama algoritmasını kullanmıştır. Bu algoritma ile elde ettikleri karar ağacının kök düğümünden iç düğümlere oradan da yaprak düğümlere doğru değişkenleri en önemli olandan en önemsiz olana doğru önem derecesine göre sıralayarak başarıyı etkileyen önemli değişkenleri belirlemişlerdir.

Diğer bir örnek olarak, Yu ve arkadaşları (2012) yaptıkları çalışmada, öğrencilerin PISA Fen okur yazarlığı başarısını yordama da Lojistik regresyon sınıflama algoritmasını kullanmış ve 
elde edilen modeldeki ODDS oranlarına göre, başarıyı yordayan önemli faktörleri belirlemişlerdir. Bu iki örnek; alanyazındaki başarıyı yordayan önemli faktörlerin belirlenmesine yönelik çalışmalarda; genellikle Modeler ve Weka programlarının kullanıldığını ifade etmektedir (Abad ve Lopez, 2016; Yu ve ark., 2012;). Bununla birlikte; Bezek Güre ve ark. (2020) yaptıkları çalışmada, SPSS Modeler ve Matlab programlarını kullanarak, başarıyı en yüksek düzeyde yordayabilen önemli değişkenleri belirlemişlerdir. Bezek Güre ve arkadaşlarının çalışması (2020) alanyazındaki diğer çalışmalardan farklıdır. alanyazındaki çalışmaların neredeyse tamamında başarıyı etkileyen faktörleri belirlemede, veri madenciliği algoritmalarından elde edilen çıktılara göre karar verilirken, Bezek Güre ve ark. (2020)'nın yaklaşımında model performansını en yüksek yapan değişkenler en iyi yordayıcılar olarak görülmektedir. Diğer yandan birinci ve ikinci grup çalışmalar arasındaki fark başarıyı yordayan değişkenleri belirlemedeki, istatistiksel yaklaşımlarla veri madenciliği yaklaşımları arasındaki farklılığı göstermektedir. İstatistiksel yaklaşımda başarıyı etkileyen faktörler, elde edilen istatistiksel modelinin çıktılarına göre ilişki temeline dayandırılırken, veri madenciliği yaklaşımında ise başarıyı yordayabilen önemli değişkenler modelin tahmin performansını en çok artıran yordayıcılar olarak görülmektedir.

Ulusal alanda, PISA verilerini kullanılarak başarıyı yordayabilen önemli yordayıcıları belirlemeyi amaçlayan VM performansına dayalı olarak Bezek Güre ve ark. (2020) çalışmasının dışında bir çalışmaya taranan kaynaklarda rastlanmamıştır. Bununla birlikte; Yue (2021) çalışmasında, kolejdeki öğrencilerin performanslarını tahmin edebilen önemli değişkenleri belirlemede Bezek Güre ve ark. (2020) yaklaşımına uygun olarak VM performansına dayalı yaklaşımı kullanmıştır. Bezek Güre ve ark. (2020) ile Yue (2021) yaklaşımlarının alanyazınki çalışmaların çoğunluğunda kullanılan VM modellerinden elde edilen çıktılara göre önemli değişkenlerin belirlenmesi yaklaşımından daha pratik olduğu söylenebilir. Çünkü; önemli değişkenlerin kullanılan modellerden elde edilen çıktılar yorumlanarak belirlenmesinde, VM tahmin modelinin performansının ne olduğu dikkate alınmamaktadır. Böylece; performansı yeterince yüksek olmayan modeller kullanılarak önemli değişkenler belirlenebilmektedir. Oysaki, Bezek Güre ve ark. (2020) ve Yue (2021)'nun önemli değişkenlerin saptanması yaklaşımı ile performansı yüksek olan bir VM tahmin modeline göre karar verilmektedir. Diğer yandan alanyazında yapılan araştırmalar incelendiğinde daha çok tek bir ülke ile sınırlı olan homojen gruplarla yapılan çalışmalar yoğunluktadır.

Farklı başarı gruplarında ve bu gruplarının birleştirilmesiyle oluşan heterojen gruplarda VM yöntemlerinden elde edilen sonuçların değişip değişmediğini, yani yordayıcı değişkenlerin ve sayısının değişip değişmediğine yönelik çalışmaya rastlanmamıştır. Aslında veriden öğrenen (akıllı) bir yöntem olduğu düşünülen VM yöntemlerinin veri (örneklem) değiştikçe farklı sonuçlar verebileceğinin araştırılması önem teşkil etmektedir.

Başarıyı yordayan değişkenleri saptamak için veri madenciliği kapsamında birçok yöntem kullanılabilir ancak kullanılan modelin performans düzeyi değiştiğinde ve çalışılan örneklemin başarı düzeyi değiştiğinde nasıl bir sonuçla karşılaşıldığını görmek için belirli bir VM kestirim tekniği ile elde edilen sonuçların karşılaştırılması yeterli olabilir. Bu araştırmada VM kestirim tekniği olarak lojistik regresyon kullanılmıştır. Lojistik regresyon tekniğinin tercih edilme nedeni ise alanyazın çalışmalarında iyi performans göstermiş olmasıdır (Büyükkıdık ve Mutluer, 2017). 
Alanyazında PISA başarı puanını yordayan önemli değişkenlerin belirlenmesi çalışmalarında kullanılan örneklemlerin de dar kapsamlı olduğu görülmektedir. Örneğin; Aksu ve Güzeller (2016) ve Bezek Güre ve ark. (2020) çalışmalarında sadece PISA Türkiye örneklemini kullanmışlardır. Yapılan çalışmalar başarı veya performansı yordayan değişkenler üzerinde yoğunlaşmakta ancak bu çalışmalar birbirine benzer şekilde fen, matematik veya okuma puanını bağımlı değişken kabul ederek sözü edilen üç alandaki başarıyı etkileyen faktörlerin açığa çıkarılmasına yöneliktir. Ancak bu çalışmalar farklı başarı düzeyleri dikkate alınarak yapılan çalışmalar değildir. Oysa farklı alt başarı gruplarında farklı değişkenlerin etkili olabileceğinden dolayı bu iddiayı farklı başarı gruplarında çalışılarak doğrulamak mümkündür.

Dolayısıyla bu araştırmada, PISA 2018 okuduğunu anlama başarısına yönelik olarak olarak, her biri 3'er ülkeden oluşan alt, orta ve üst başarı grubuna sahip ülkeler ve bu ülkelerin birleştirilmesiyle oluşturulan çalışma örneklemi, dikkate alınmıştır. Böylece, bu çalışmada seçilen örneklemlerin çeşitli olması, farklı başarı gruplarını dikkate alınması, homojen ve heterojen gruplara ilişkin sonuçlar elde edilmesi ve örneklemin yeterince büyük olması nedeniyle evrenin temsil edilme veya sonuçların genelenebilirlik düzeyinin artması beklenebilir.

Birçok ülkenin katıldığı PISA'da ülkelerin başarı düzeyleri birbirinden oldukça farklıdır. Bu nedenle; bu çalışmada; alt, orta ve üst başarı grubundaki ülkeler için başarıyı etkileyen değişkenlerin belirlenmesi ile ilgili gruptaki ülkelerin eğitim politikalarına yön verirken başarıyı olumlu etkileyen faktörlere daha fazla önem vermeleri sağlanabilir. Diğer yandan farklı başarı düzeylerinde ülkeler için; başarıyı etkileyen aynı ve farklı faktörlerin neler olduğu saptanarak, düşük başarı düzeyindeki ülkelerin başarılarını artırmada daha doğru kararlar almaları sağlanabilir. $\mathrm{Bu}$ araştırmanın bu bakımdan alanyazına katkı sağlayacağı düşünülmektedir.

$\mathrm{Bu}$ araştırmanın temel amacı, PISA öğrenci anketinde bulunan 34 bağımsız değişkene ilişkin puanları kullanarak farklı başarı düzeyine sahip (alt, orta ve üst başarı grubundaki) ülkelerin okuduğunu anlama başarısını etkileyen önemli yordayıcıları belirlemektir.

Çalışmanın diğer amacı ise; belirlenen az sayıda daha önemli bağımsız değişkenleri kullanılarak performansı yüksek sinıflama modellerinin elde edilip edilmeyeceğini göstermektir. Böylece; çalışmanın, VM performansını en yüksek yapan daha önemli bağımsız değişkenleri seçerek değişken sayısını azaltmaya yönelik az sayıda çalışmadan biri olması hedeflenmektedir.

\section{Araştırma Problemleri}

1- PISA okuma alanındaki alt, orta, üst başarı grubundan seçilen üçer ülkeden oluşan örneklemlerin, seçilen ülkelerin birleştirilmesiyle oluşturulan çalışma örnekleminin ve Türkiye örnekleminin başarı durumunu yordama da önemli olan değişkeler nelerdir?

2- PISA okuduğunu anlama başarısını yordayan önemli değişkenler ve tüm değişkenlerin tahmin performans düzeyleri nasıldır? 


\section{Yöntem}

\section{Araştırma Modeli}

Araştırmada öğrencilerin duyuşsal özelliklerini ölçen ölçekler ve sosyodemografik özelliklerini ölçen anketlerle alt, orta, üst başarı grubundan seçilen ülkeler, seçilen ülkelerin birleştirilmesiyle oluşturulan PISA uygulama örneklemi ve bağımsız olarak Türkiye örnekleminin başarı düzeylerinin PISA okuduğunu anlama puanlarına göre (başarılıbaşarısız) tahmin yapılması açısından etkili olan değişkenlerin belirlenmesi amaçlandığından araştırmanın modeli ilişkisel nicel araştırma tasarımı olarak ifade edilebilir (Büyüköztürk ve ark., 2018).

\section{Evren ve Örneklem}

Çalışmanın amacı için ülkeler; PISA okuma puanı sıraları dikkate alınarak alt (zayıf), orta, üst (yüksek) başarı grubuna göre belirlendiği için amaçlı örnekleme yöntemi kullanılmıştır. Çünkü amaçlı örnekleme derinlemesine araştırma yapabilmek amacıyla çalışmanın amacı bağlamında bilgi açısından zengin durumların seçilmesidir (Büyüköztürk ve ark., 2018). Ayrıca, Çalışma örneklemine ülkeler seçilirken kayıp veri oranının düşük olmasına ve farklı yüzdelik dilimlere dağılacak şekilde örüntü oluşturmasına dikkat edilmiştir. Böylece çalışma grubunu sağlayacağı bilgilerin zenginleşmesi sağlanmıştır.

PISA 2018 uygulaması, 37'si OECD üyesi olmak üzere 79 ülkeden 612004 öğrencinin katılımıyla gerçekleştirilmiştir. PISA'ya katılacak okul ve öğrencilerin seçim işlemi, OECD tarafından iki aşamalı tabakalı tesadüfi yöntemle belirlenmektedir (MEB, 2019). Çalışma evrenini 2018 PISA'ya katılan ülkelerdeki 15 yaş grubu öğrencilerin tamamı oluşturmaktadır. $\mathrm{Bu}$ araştırmanın hedeflerine göre PISA 2018 sınavına katılan ülkelerin tamamından 9 ülke çalışma örneklemi olarak seçilmiştir. Bu 9 ülke; 79 ülke içindeki başarı puanlarına göre yüzdelik sıralamaları dikkate alınarak belirlenmiştir. Son üçte birlik (\% 68-100) başarı sırasındaki dilimden seçilen ülkelerin yüzdelik sırası Endonezya için 91, Suudi Arabistan için 82 ve Kolombiya için 73 tür. Böylece; Endonezya, Suudi Arabistan ve Kolombiya örneklemi, son \% 33'lük dilimdeki en başarısız ülkeleri temsil edecek şekilde alt başarı grubu ülkeler olarak adlandırılmıştır. \% 33 ile \% 67'lik başarı diliminden seçilen ülkelerin yüzdelik sırası ise; Sırbistan için 57, Türkiye için 50 ve Macaristan için 41'dir. Böylece; Sırbistan, Türkiye ve Macaristan örneklemi, \% 33 ile \% 67'lik dilim aralığındaki orta düzeyde başarılı ülkeleri temsil edecek şekilde orta başarı grubu ülkeler olarak adlandırılmıştır.

Son olarak; İlk üçte birlik başarı sırasındaki dilimden seçilen ülkelerin yüzdelik dilimleri sırası ile; Slovenya için 27, ABD için 16 ve Finlandiya için 9 dur. Böylece; Slovenya, ABD ve Finlandiya örneklemi, ilk \% 33'lük dilimdeki en başarılı ülkeleri temsil edecek şekilde üst başarı grubu ülkeler olarak adlandırılmıştır. Bu 9 ülkenin tamamı ise; PISA'nın uygulandığı 79 ülkeyi temsil edecek şekilde PISA uygulama örneklemi olarak adlandırılmıştır. Bu durumda araştırmaya, alt grup ülkeler için 25378, orta başarı grubu ülkeler için 18523, üst başarı grubu ülkeler için 16567 kişi dahil edilmiştir. Alt, orta ve üst başarı grubu olmak üzere her bir grupta 3 ülkenin bulunduğu ve ülkelerin birleştirilmesi ile araştırmaya alınan toplam 9 ülkenin örneklem büyüklüğü 60468 kişiye ulaşmaktadır. Yüzdelik dilimler belirlenirken Türkiye \% 50. dilimde olduğu için araştırmada orta grupta yer almıştır. Diğer yandan Türkiye'nin araştırma kapsamında bağımsız olarak incelenmesi uygun görülerek Türkiye için aynı analizler 6859 kişi üzerinden yürütülmüştür. 


\section{Veri Toplama Araçları}

Araştırma sürecinde kullanılan veriler 2020 yılında paylaşıma açılan veri tabanından http://www.oecd.org/pisa/data/2018database/ adresi kullanılarak elde edilmiştir. Araştırma kapsamına 2018 PISA verilerine ait toplamda 34 bağımsız ve okuduğunu anlama başarı düzeyine karşılık gelen on makul değerin ortalaması olan bir bağımlı değişken alınmıştır. Veriler incelendiğinde bağımlı değişkene ilişkin kayıp veriye rastlanmamıştır. Ancak, 34 bağımsız değişkene ilişkin yanıt vermeyen bireyler analizden çıkarıldıktan sonra saptanan az sayıda uç değerler SPSS programı kullanılarak verilerden çıkarılmıştır. Ayrıca tüm bağımsız değişkenlerin her birinde kayıp veriye rastlanmıştır. Bu bağımsız değişkenlere yönelik kayıp veriler tesadüfi dağıldığı için SPSS programı kullanılarak çoklu atama yöntemi ile atama yapilmıştır.

\section{Veri Toplaması ve Verilerin Analizi}

Araştırmada veriler 2018 yılında uygulanan PISA okuduğunu anlama sınavındaki test ve öğrenci anketinden elde edilmiştir. Kullanacağımız bağımlı değişkeni elde etmek için öncelikle okuduğunu anlama başarı puanı sürekli nicel değişken olarak elde edilmiş ve PVREAD olarak adlandırılmıştır. Burada PVREAD makul okuduğunu anlama başarı puanını ifade eder. PVREAD değişkeni PISA 2018 okuduğunu anlama başarı testinden her bir öğrencinin aldığı ve öğrencilerin sahip olabileceği yetenekler yelpazesini ifade eden (Wu ve Adams, 2002), 10 makul puan değerinin (PV1,PV2,...,PV10) ortalamasıdır. Daha sonra, PVREAD puanının sınıflandırılması sürecinde PISA 2018 Türkiye ön raporundaki, okuma becerileri yeterlilik düzeyi tablosu kullanılmıştır (MEB, 2019). PISA ön raporunda verilen eşik değerler revize edilerek, PISA 2018 okuma becerileri yeterlilik düzey sayısı 8'den 6'ya indirgenecek şekilde Tablo 1'de verilen; PISA 2018 okuduğunu anlama becerisi yeterlik düzeylerinin eşikleri ve kategori bilgileri elde edilmiştir. Bu indirgeme PISA 2018 raporunda belirtilen 1. düzeydeki 1a, 1b, 1c düzeylerinin birleştirilip tek düzey olarak alınması ve Düzey 6, Düzey 7 ve Düzey 8 birleştirilerek Düzey 6 olarak belirlenmesi işlemleriyle yapılmıştır.

Tablo 1. PISA 2018 Okuduğunu Anlama Becerisi Yeterlik Düzeylerinin Kategorileri

\begin{tabular}{lll}
\hline Yeterlilik seviyeleri & Puan(x) & Kategori \\
\hline Düzey 1 & $0<X<407$ & Düşük \\
Düzey 2 & $407<X<480$ & Düşük \\
Düzey 3 & $480<X<553$ & Düşük \\
Düzey 4 & $553<X<626$ & Yüksek \\
Düzey 5 & $626<X<698$ & Yüksek \\
Düzey 6 & $698<X<1000$ & Yüksek \\
\hline
\end{tabular}

Tablo 1 incelendiğinde eşik değerleri kullanılarak, iki düzeyli başarı değişkeni; PVREAD değeri 0-552,999 arası düşük ve 553-1000 arası yüksek olacak şekilde sınıflanarak elde dilmiştir (0=Başarısız, 1=Başarılı). Ayrıca, veri madenciliği modelinde kullanılacak 34 bağımsız değişken ise, alanyazındaki çalışmalarda en çok kullanılan değişkenler dikkate alınarak, Tablo 2'de verildiği gibi belirlenmiştir. 
Tablo 2. Araştırma Sürecinde Kullanılan Bağımsız Değişkenler ve PISA 2018 Kodları

\begin{tabular}{|c|c|c|c|}
\hline Değişken Adı & Kodu & Değişken Adı & Kodu \\
\hline İleri düzey görevlere motivasyon & WORKMAST & BİT kaynakları & ICTRES \\
\hline Olumlu duygular & SWBP & Öğrenciden beklenen mesleki statü & BSMJ \\
\hline Öz yeterlik & RESILIENCE & Ebeveynlerin duygusal desteği & EMOSUPS \\
\hline Yaşamın anlamı & EUDMO & Test dili öğrenme süresi & LMINS \\
\hline Öğretmenin okumaya teşviki & STIMREAD & Okula ait hissetme & BELONG \\
\hline Öğrenci işbirliği & PERCOOP & Evdeki eğitim kaynakları & HEDRES \\
\hline Okulun değeri & ATTLNACT & Öğretim adaptasyonu & ADAPTIVITY \\
\hline Öğgretmen Coşkusu & TEACHINT & Rekabete karşı tutumlar & COMPETE \\
\hline Okuma keyfi & JOYREAD & Zorbalığa maruz kalma & BEINGBULLIED \\
\hline Anne eğitim düzeyi & MISCED & Başarısızlık korkusu & GFOFAİL \\
\hline Baba eğitim düzeyi & FISCED & Öğrenme amaçları & MASTGOAL \\
\hline Disiplin İklimi & DISCLIMA & Ailenin mal varlığ 1 & WEALTH \\
\hline Öğretmen desteği & TEACHSUP & Okuma yetkinlik algisı & SCREADCOMP \\
\hline Evdeki eğitimsel eşyalar & HOMEPOS & Okuma zorluk algısı & SCREADDIFF \\
\hline Öğretimin yönlendirilmesi & DIRINS & PISA testinin zorluk alg1sı & PISADIFFF \\
\hline Sosyo-ekonomik durum indeksi & ESCS & Öğretmen geri bildirimi & PERFEED \\
\hline Öğrenci rekabeti & PERCOMP & Okuduğunu anlama başarısı & PVREAD \\
\hline $\begin{array}{l}\text { Ebeveylerin en yüksek mesleki } \\
\text { staüsü }\end{array}$ & HISEI & & \\
\hline
\end{tabular}

Verilerin analizinde; öncelikle PISA'ya katılan 79 ülke başarı yüzdelik sırasına konuldu. Ardından eşit dilimlerle ülkeler alt, orta ve üst dilimler olarak ayrıldı. Yüzdelik dilimlerine ve kayıp veri azlığına göre Türkiye dahil 9 ülke seçildi. Veriler analiz edilirken önce bağımsız olarak Türkiye verileri, sonra alt, orta ve üst başarı grupları ardından da seçilen ülkelerin birleştirilmiş verileri analiz edilmiştir. Verilerin analizinde SPSS Modeler, WEKA, SPSS ve Excel programları kullanılmıştır. Araştırma kapsamında Tablo 2'de verilen 34 değişken bağımsız değişken olarak ve iki düzeyli başarı değişkeni (0=başarısız, 1=başarılı) bağımlı değişken olarak alınmıştır. Bağımsız değişkenlerin bağımlı değişkeni sınıflama performansını belirlemek için Lojistik regresyon veri madenciliği sınıflama modeli kullanılmıştır. Öncelikle; SPSS Modeler programı kullanılarak 2 düzeyli başarı değişkenini yordayan önemli bağımsız değişkenler saptanmıştır. Elde edilen önemli bağımsız değişkenler kullanılarak Weka programında; eğitim verisi, 10 katlı çapraz geçerlik verisi ve test verisi ile geçerliğe ve güvenirliğe dayalı performans kriterleri hesaplanmıştır. $\mathrm{Bu}$ hesaplanan performans kriterlerinin 34 bağımsız değişken kullanıldığında hesaplanan performans kriterlerinden önemli düzeyde bir farklılığa sahip olmadığı belirlenmiş ve böylece başarıyı tahmin etmede, daha az değişken ile yüksek performansa sahip modeller kurulabildiği gösterilmiştir. Bu analizler, Türkiye, alt, orta, üst başarı grubu ülkeler ve çalışma örneklemi için iki düzeyli bağımlı değişken hesaplanarak yapılmış ve elde edilen sonuçlar ayrıntılı bir karşılaştırma yapılarak yorumlanmıştır. 
Sonuçları karşılaştırmada kullanılan mutlak ve bağıl performans kriterleri 1.,2., 3., 4., 5., 6., ve 7. formüllerde verilmiştir (Tabachnick ve Fidel, 2007; Field, 2009). Mutlak performans kriterleri olan Doğru Sınıflama Oranı (DSO), Roc Alanı, Hata Kareler Ortalamasının Karekökü (HKOK) ve Ortalama Mutlak Hata (OMH) hesaplama formülleri 1., 2., 3. ve 4. denklemlerde verilmiştir.

$D S O=\frac{D P+D N}{D P+D N+Y P+Y N}$

Roc alanı $=\Phi\left(\frac{a}{\sqrt{1+b^{2}}}\right)$

$H K O K=\sqrt{\frac{\sum_{i=1}^{N}\left(P_{i}-O_{\mathrm{I}}\right)^{2}}{N}}$

$O M H=\frac{\sum_{i=1}^{N}\left|P_{i}-O_{i}\right|}{N}$

Formül (1)'de DP doğru pozitif, DN doğru negatif, YP yanlış pozitif, YN yanlış negatif durumların sayısını göstermektedir. Formül (2)' de $a, b$ sırasıyla Roc eğrisinin kesişim ve eğim parametrelerini, $\Phi$ ise birikimli (kümülatif) normal dağılım fonksiyonunu ifade etmektedir. (3) ve (4) formüllerinde; $P_{i}$ tahmin edilen değerleri, $O_{i}$ gözlenen değerleri göstermektedir. HKOK ve OMH sıfıra yakın olmalıdır.

Bağıl performans kriterleri olan; Kappa $(\kappa)$ katsayısı, Göreli Hata Karelerinin Karekökü (GHKK) ve Göreli Mutlak Hata (GMH) hesaplama formülleri (5), (6) ve (7)' de verilmiştir.

$\operatorname{Kappa}(\kappa)=\frac{\text { Gözlenen doğruluk-Beklenen doğruluk }}{1-\text { Beklenen doğruluk }}$

$G H K K=\sqrt{\frac{\sum_{j=1}^{n}\left(P_{i j}-O_{j}\right)^{2}}{\sum_{j=1}^{n}\left(O_{j}-\bar{O}\right)^{2}}}$

$G M H=\frac{\sum_{j=1}^{n}\left|P_{j}-o_{j}\right|}{\sum_{j=1}^{n}\left|o_{j}-\bar{O}\right|}$

(5),(6) ve (7) formüllerinde; $P_{j}$ ve $P_{i j}$ tahmin edilen değerleri, $O_{j}$ gözlenen değerleri, $\bar{O}$ ise gözlenen değerler ortalamasını göstermektedir.

\section{Lojistik Regresyon Modeli}

Basit ve çoklu doğrusal regresyon modelinde bağımlı değişken eşit oranlı ya da eşit aralıklı ölçek düzeyindedir. Ancak bağımlı (yordanan) değişkenin iki veya daha fazla sınıflı olduğu durumda doğrusal regresyon yöntemlerinde parametre kestirimlerinde kullanılan en küçük kareler yöntemini kullanmak normal dağılıma uymayan hata terimi gibi bazı varsayımların sağlanamamasından dolayı uygun olmamaktadır.

Bu durumda lojistik regresyon kullanmak uygun olmaktadır. İki sınıflı lojistik regresyonda, $Y_{i}$ , Bernoulli olasılık dağılımına sahip rasgele değişkenin 1 değerini alma olasılığı, $\pi_{i}$ ve 0 değerini alma olasılığ ise $\left(1-\pi_{i}\right)$ olur. 
Bağımsız (yordayıcı) değişkenler $X=\left(X_{1}, X_{2}, X_{3}, \ldots \ldots \ldots \ldots X_{n}\right)$ biçiminde ifade edildiği durumda, herhangi $i^{\prime}$ inci gözlemin regresyon modeli $Y_{i}=\beta_{0}+\beta_{1} X_{i}+\varepsilon_{i}$ biçiminde gösterilen modelde bulunan bağımsız değişkenler için bir kısıtlama yoktur. Bu modelde $Y_{i}$ bağımlı değişkeni $-\infty$ ile $+\infty$ arasında sayıda değer alabilmektedir. Ancak bağımlı değişkenin alacağ 1 0 ve 1 değerleri için model yapısal olarak değişmektedir.

$P\left(Y_{i}=1\right)$ i'inci gözlemin 1 değerini alma olasılığ 1 olduğundan $E\left(\varepsilon_{i}\right)=0$ olduğu için $Y_{i}^{\prime}$ nin beklenen değeri; $E\left(Y_{i}\right)=1 . P\left(Y_{i}=1\right)+0 . P\left(Y_{i}=0\right)=P\left(Y_{i}=1\right)$ olacaktır. Bağımlı değişken iki kategorili olduğu durumda $\left(0 \leq E\left(Y_{i}\right)=P\left(Y_{i}=1\right) \leq 1\right)$ olduğundan en büyük sinırlama bağımlı değişkenin beklenen değeri üzerinde olacaktır. Bunun sonucunda;

$E\left(Y_{i}\right)=P\left(Y_{i}=1\right)=\beta_{0}+\beta_{1} X_{i}$ olarak ifade edilebilir. Bu model bağımlı değişkeni 0 ile 1 arasında olasılık değeri alan "Doğrusal olasılık modeli" olarak adlandırılır (Tatlıdil, 1996). Daha sonra bu sınırlamanın önüne geçmek için ilk olarak;

$E\left(Y_{i}\right)=P\left(Y_{i}=1\right)=\beta_{0}+\beta_{1} X_{i}$ modelindeki olasılık değerlerinde $\frac{P}{1-P}($ Odds $)$ dönüşümü yapılarak bağımlı değişkenin sınırları 0 ile $+\infty$ aralığı olarak sonrada $\frac{P}{1-P}$ oranının doğal logaritması alınıp lojit dönüşümü yapılarak bağımlı değişkenin sınırları $-\infty$ ile $+\infty$ olarak genişletilir. Dönüşümler sonucunda elde edilen model:

$\ln \left[\frac{E\left(Y=1 / X_{i}\right.}{E\left(Y=0 / X_{i}\right.}\right]=\ln \left[\frac{P_{i}}{1-P_{i}}\right]=\beta_{0}+\beta_{1} X_{i}$ olur. Bu model lojistik model veya lojit model olarak adlandırılır (Hosmer ve Lemeshow, 2000). Modelden elde edilen olasılık değeri ise:

$P_{i}=\frac{\exp \left(\beta_{0}+\beta_{1} X_{i}\right)}{1+\exp \left(\beta_{0}+\beta_{1} X_{i}\right)}$ olarak ifade edilir (Collet, 2003).

Lojistik regresyon modelinde en çok olabilirlik yöntemi kullanılarak model katsayıları kestirilir. Bu yöntem ile kestirilen katsayıların anlamlılığı Wald testi veya $G$ istatistiği ile elde edilir. Lojistik modelde bulunan "başarılı olmanın", "başarılı olmamaya oranı" $\frac{P}{1-P}$ ile gösterilip bu oran "Odds" olarak bilinir. Bu oran $0 \leq O d d s \leq+\infty$ aralığında değer alıp lojistik regresyon modelinde değişkenlere ait katsayıların yorumunda kullanılır. 0 ile 1 arasında değer alırsa başarısızlık olasılığı başarılı olma olasılığından daha fazla, 1 olursa başarısız olma olasılığ i ile başarılı olma olasılığı eşit, 1'den büyük olursa başarılı olma olasılığ 1 başarısız olma olasılı̆̆ından daha fazladır.

\section{Bulgular}

Lojistik regresyon analizi yapılırken öncelikle başarı puanı 553'den küçük olan puanlar 0 (başarısız) olarak ve başarı puanı 553 ya da daha büyük olan puanlar 1 (başarılı) olarak alınarak, iki düzeyli başarı durumu değişkeni elde edilmiştir. Ardından çalışmanın ana amacına uygun olarak, öncelikle, 34 bağımsız değişkenden başarıyı yordayabilen ilk 10 değişken saptanmıştır. Uygulama, SPSS Modeler programında Lojistik regresyon veri madenciliği algoritması kullanılarak gerçekleştirilmiş ve ilk 10 değişkene ilişkin yordayıcı önem düzeyi grafikleri Şekil 1' de verilmiştir. 

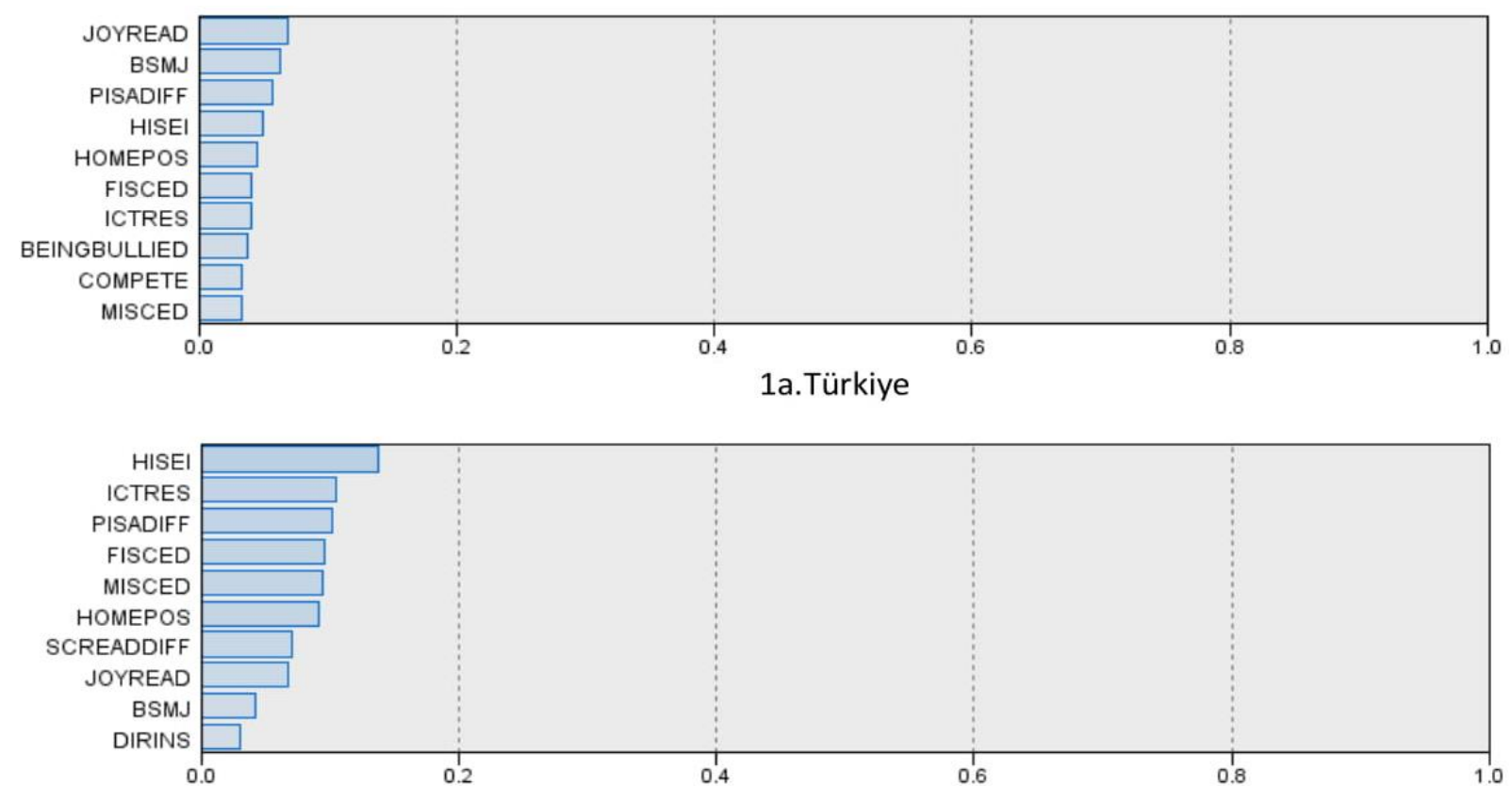

1b. Alt grup
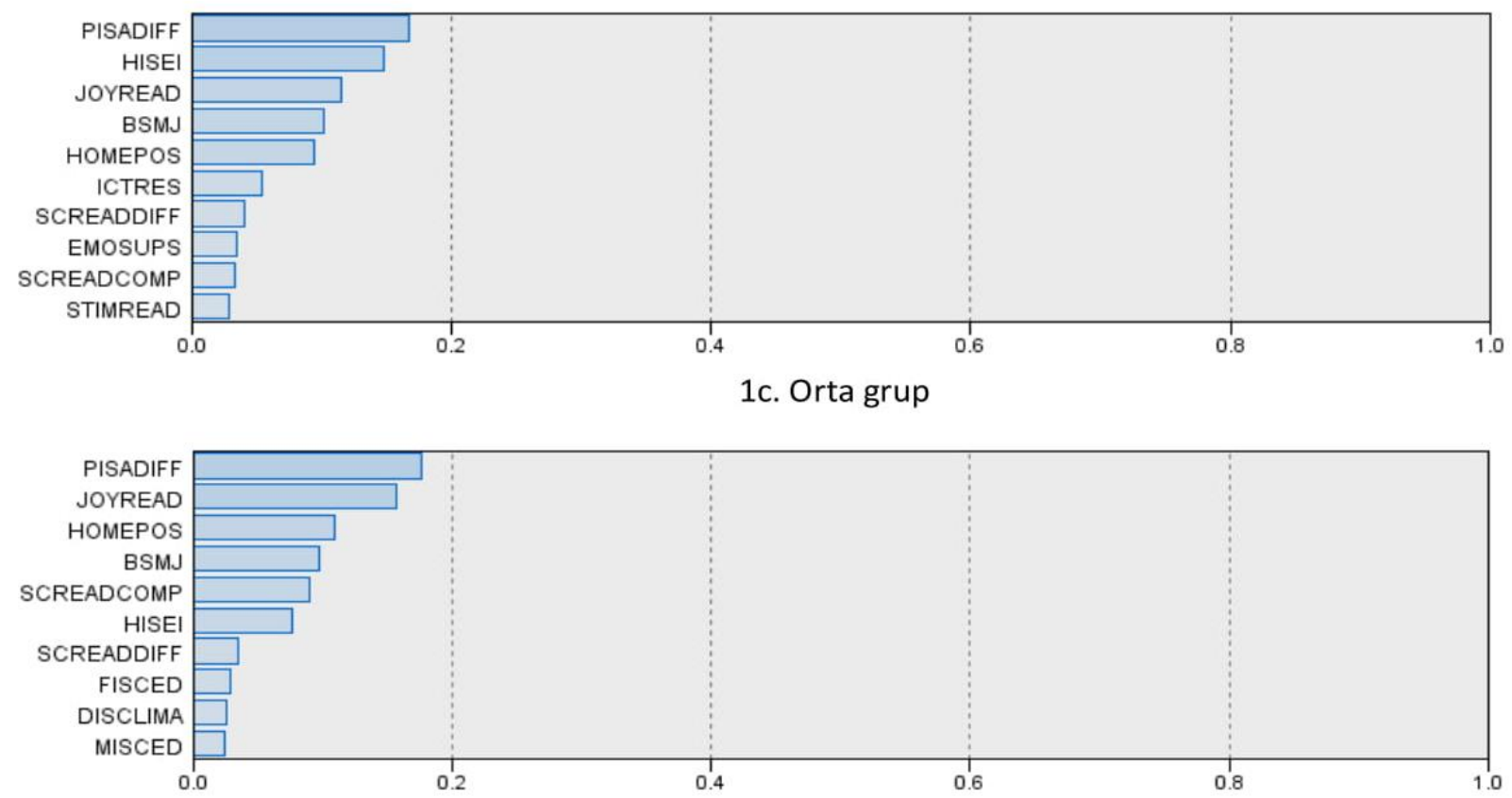

1d. Üst grup

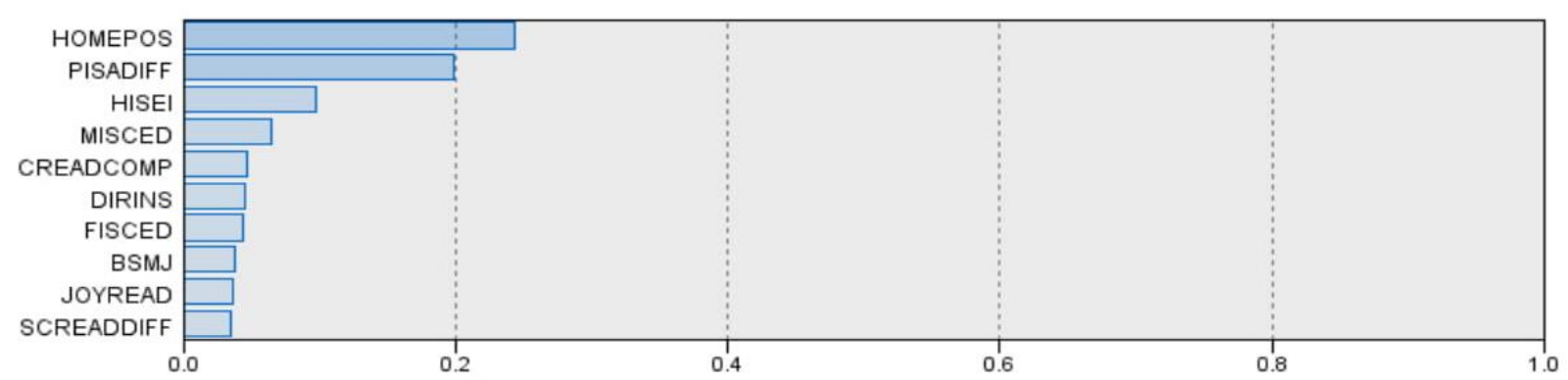

1e. Çalışma örneklemi

Şekil 1. Okuduğunu Anlama Başarısını Yordayan Değişkenler ve Yordayıcı Önem Düzeyleri 


\section{Birinci araştırma sorusuna ilişkin bulgular}

Şekil 1'deki grafiklere göre; başarıyı yordayan birinci sırada önemli değişkenler; Türkiye için okuma keyfi (JOYREAD), alt başarı grubundaki ülkeler için ebeveynlerin en yüksek mesleki statüsü (HISEI), orta ve üst başarı grubundaki ülkeler için PISA testinin zorluk algısı (PISADIFF) ve çalışma örneklemi için evdeki eğitimsel eşyalar (HOMEPOS) olarak elde edilmiştir. Şekil 1'de her bir grup için elde edilen PISA okuduğunu anlama başarısını yordama derecesine göre seçilen ilk 10 bağımsız değişkenin sayısını azaltmak için "yordayıcının önem düzeyi" en az \% 5 alınarak "PISA okuduğunu anlama başarısını en iyi yordayan" yeterli sayıda bağımsız değişken saptanarak Tablo 3'de sunulmuştur. Tablo 3 incelendiğinde, her bir grup için, yordayıcı değişkenlerin önem sırası, logistik regresyon katsayısının işareti tablo içinde belirtilmiş ve önemli ortak değişkenler aynı sırada yazılmıştır.

Tablo 3. Okuduğunu Anlama Başarısını Yordayan Önemli Değişkenler

\begin{tabular}{|c|c|c|c|c|}
\hline Türkiye & Alt Grup & Orta Grup & Üst Grup & Çalışma örneklemi \\
\hline 3.(-)PISADIFF & 3.(-)PISADIFF & 1.(-)PISADIFF & 1.(-)PISADIFF & 2.(-)PISADIFF \\
\hline 4.(+)HISEI & 1.(+)HISEI & 2.(+)HISEI & 6.(+)HISEI & 3.(+)HISEI \\
\hline 5.(+)HOMEPOS & 6.(+)HOMEPOS & 5.(+)HOMEPOS & 3.(+)HOMEPOS & 1.(+)HOMEPOS \\
\hline 1.(+)JOYREAD & 8.(+)JOYREAD & 3.(+)JOYREAD & 2.(+)JOYREAD & - \\
\hline 2.(+)BSMJ & - & 4. $(+) \mathrm{BSMJ}$ & 4. $(+)$ BSMJ & - \\
\hline- & 2.(+)ICTRES & 6.(+)ICTRES & - & - \\
\hline- & 5.(+)MISCED & - & - & 4.(+)MISCED \\
\hline- & - & - & 5.(+)SCREADCOMP & 5.(+)SCREADCOMP \\
\hline- & 4.(+)FISCED & - & - & - \\
\hline- & 7.(-)SCREADIFF & - & - & - \\
\hline
\end{tabular}

-,+:Lojistik regresyon modelindeki beta katsayısının işareti, 1,2,3,...: Önemli değişkenlerin önem sıralaması

Tablo 3'de, lojistik regresyon beta katsayılarının işaretine göre, PISA testinin zorluk alg1Sı (PISADIFF) ve okuma kavramı zorluk algısı (SCREADIFF) değişkenlerinin PISA okuduğunu anlama başarı durumunu yordama da negatif, diğer değişkenlerin ise pozitif etkiye sahip oldukları görülmektedir. Bu sonuç eğitim açısından doğal bir sonuç olup; bu değişkenlere yönelik zorluk algısı arttıkça başarının azalacağını ifade eder. PISADIFF ve SCREADIFF değişkenleri dışındaki değişkenler, başarıyı pozitif etkileyen değişkenler olduğundan, lojistik regresyon beta katsayıları pozitif değerler olarak elde edilmiş olup, bu değişkenler başarıyı artıcı etkiye sahip yordayıcılar olarak yorumlanabilir. PISADIFF, ebeveynlerin en yüksek mesleki statüsü (HISEI) ve evdeki eğitimsel eşyalar (HOMEPOS) değişkenleri tüm analizlerde PISA okuduğunu anlama başarısını yordama da önemli ortak değişkenler olarak saptanmıştır. 
PISADIFF değişkeni tüm analizlerde, birinci, ikinci veya üçüncü sırada öneme sahip değişken olarak saptanmıştır. Bu sonuca dayanarak PISA testinin zorluk algısının, PISA okuduğunu anlama başarı durumunu yordama da önemli tahmin edicilerden biri olduğu söylenebilir. Bununla birlikte HISEI değişkeninin alt ve orta başarı grubu ülkelerde birinci veya ikinci sırada öneme sahip olduğu görülmektedir. Bu bulgu, orta düzey veya daha düşük düzeydeki ülkelerde, ebeveynlerin eğitim düzeyi değişkeninin, öğrencilerin PISA okuduğunu anlama başarı durumunu tahmin eden önemli yordayıcı olduğunu göstermektedir. Ayrıca, başarıyı yordama bakımından HOMEPOS değişkeni çalışma örneklemi üzerinde yapılan analizde ilk sırada öneme sahip çıkmıştır. Dolayısıyla çalışma örneklemi için evdeki eğitimsel eşyaların miktarının, PISA okuduğunu anlama başarı durumunu artırıcı en etkili değişken olduğu söylenebilir.

Tablo 3 incelendiğinde, okuma keyfi (JOYREAD) çalışma örneklemi için, okuduğunu anlama başarı durumunu yordayan önemli değişkenler arasında değildir. Bununla birlikte JOYREAD; Türkiye, alt, orta ve üst başarı grubu analizlerinde PISA okuduğunu anlama başarı durumunu yordayan önemli değişkenlerden biri olarak ortaya çıkmaktadır. Ayrıca, JOYREAD değişkeni Türkiye analizlerinde PISA okuma puanlarını yordayan önem sırası en yüksek değişken olarak saptanmıştır. Bu bulgu, Türkiye'nin PISA başarısı sıralamasında orta başarı grubunda yer almasına rağmen, okuma keyfi değişkeninin, okuduğunu anlama başarısını artırmada üst başarı grubu ülkelerden bile daha önemli bir etkiye sahip olduğunu göstermektedir. Böylece; JOYREAD değişkeni, alt başarı grubunda sadece sekizinci sırada yer alırken, Türkiye için üst başarı grubundan bile üst sırada yer alarak PISA okuma başarısını birinci sırada yordayabilen değişken olarak belirlenmiştir. Dolayısıyla, okuma keyfi değişkeni bakımından, Türkiye'nin, orta başarı grubu ülkelerden çok üst başarı grubu ülkeler ile benzerlik gösterdiği söylenebilir.

Öğrenciden beklenen mesleki statü (BSMJ) değişkeni başarıyı yordama da orta, üst başarı grubu ülkeler ve Türkiye'de önemli değişkenlerden biriyken, alt başarı grubu ve çalışma örneklemi analizlerinde önemli değişkenler arasında bulunmamıştır. BSMJ değişkeni Türkiye örnekleminde ikinci sırada öneme sahipken orta ve üst başarı grubu ülkelerde dördüncü sırada yer almaktadır. Bu bulgu, Türkiye' deki öğrencilerden beklenen mesleki statünün diğer ülkelere göre başarıyı daha fazla etkileyen bir değişken olduğunu gösterebilir.

Bilgi İletişim Teknojileri (BİT) kaynakları (ICTRES) değişkeni alt ve orta başarı grubu analizlerinde başarıyı yordama da önemli değişkenlerdendir. ICTRES değişkeni alt başarı grubu ülkeler için ikinci sırada bir öneme sahipken orta başarı grubu ülkeler için altıncı sırada öneme sahiptir. Bu bulgu, alt başarı grubu ülkelerde bilgi iletişim teknolojilerinin gelişmiş ülkelere göre başarıyı tahmin etmede daha etkili bir tahmin edici olduğunu gösterebilir. ICTRES değişkeni yönünden Türkiye'nin üst başarı grubu ülkelere benzer olduğu söylenebilir.

Anne eğitim düzeyi (MISCED) değişkeni alt başarı grubu ve çalışma örneklemi analizlerinde başarıyı yordama da önemli değişkenlerden biri olarak belirlenirken, Türkiye, orta ve üst başarı grubu analizlerinde önemli değişkenler arasında bulunmamıştır. Bu bulgu, alt başarı grubu ülkelerde anne eğitim düzeyinin PISA okuduğunu anlama başarısını belirlemede önemli olduğunu, fakat orta ve üst başarı grubu ülkelerde önemli olmadığını göstermiştir.

Okuma kavramı yetkinlik algısı (SCREADCOMP) değişkeni üst başarı grubu ve çalışma örneklemi analizlerinde okuduğunu anlama başarısını yordama da önemli değişkenler arasındadır. Bu değişkenin, Türkiye, alt ve orta başarı grubu ülkeler için, PISA başarı 
durumunu belirleyen önemli değişkenlerden biri olmamasına karşın, üst başarı grubu ülkelerde önemli değişkenlerden biri olduğu görülmektedir.

Baba eğitim düzeyi (FISCED) ve okuma kavramı zorluk algısı (SCREADIFF) değişkelerinin sadece alt başarı grubu ülkelerde PISA başarı durumunu yordama da önemli değişkenlerden olduğu görülmektedir.

\section{Íkinci araştırma sorusuna ilişkin bulgular}

İkinci araştırma sorusuna cevap verebilmek için 34 bağımsız değişken ve PISA okuduğunu anlama başarısı bağımlı değişkeni kullanılarak; eğitim verisi, çapraz geçerlik verileri (Araştırmacının kararına göre katmanlara ayrılmış veriler) ve test verisi için analizler yapılıp model performans kriterleri Weka programında hesaplanmıştır. Daha sonra, aynı hesaplamalar, başarı durumunu yordama derecesine göre seçilen ilk 10 bağımsız değişken ve bu 10 bağımsız değişkenden Tablo 3'te verilen “\% 5 yada daha büyük yordayıcı önem düzeyi” ölçütüne göre seçilen daha az sayıdaki önemli değişken kullanılarak, performans kriterleri tekrar hesaplanmış ve elde edilen tüm sonuçlar Tablo 4' de verilmiştir. Bu uygulamadaki amaç, yordama önem sırasına göre ilk 10 değişkenle veya daha az sayıdaki daha önemli değişkenlerle çalışıldığında, model performansının nasıl değiştiğini ortaya çıkarmaktır. Elde edilen sonuçlar başarıyı yordama da, 34 değişkeni kullanmadan, sadece 10 veya daha az sayıdaki değişkenin yeterli olup olmadığını gösterebilecektir. Tablo 4 incelendiğinde Türkiye, alt, orta, üst başarı grubu ve çalışma örneklemine ilişkin eğitim verisi, çapraz geçerlik verisi ve test verisi kullanılarak yapılan analizlerde; okuduğunu anlama başarısını yordama derecesine göre seçilen ilk 10 değişken ve bu değişkenlerden yordayıcıllğı en yüksek 10'dan az sayıdaki önemli değişkenler kullanıldığında, performansların 34 bağımsız değişken kullanılarak yapılan tahminlerdeki performanslar ile yaklaşık aynı değerlere sahip olduğu görülmektedir. Örneğin; Türkiye' de 34 tane bağımsız değişken için başarı oranı \% 86,324'iken 10 tane bağımsız değişken için başarı oranı \% 85,741, 5 tane önemli değişkenler için \% 85,034' dir. Böylece, Türkiye için, değişken sayısının azalmasının doğru sınıflama oranı (DSO) üzerinde önemli bir değişikliğe neden olmadığı söylenebilir. Uygulamaların tamamında, DSO için elde edilen yakın sonuçların diğer performans kriterleri içinde geçerli olduğu Tablo 4'te görülebilir. Bu bilgilere dayanarak, örneğin alt grup için 34 değişkenden elde edilen doğru sınıflama oranına 8 değişkenle yaklaşık olarak ulaşıldığı söylenebilir. Benzer sonuçların orta, üst başarı grubu ve çalışma örneklemi analizleri için de elde edildiği görülmektedir. Bununla birlikte lojistik regresyon analiziyle kurulan modelin doğru sınıflama oranı bakımından en başarılı olandan en başarısız olana doğru sıralaması alt başarı grubu ülkeler, çalışma örneklemi, Türkiye, orta başarı grubu ve üst başarı grubu ülkeler şeklindedir. Buna ek olarak alt başarı grubu ülkelerde kappa katsayısı 0,20'in altında olduğu için düşük, GMH (göreli mutlak hata) ve GHKK (göreli hata karelerinin karekökü) değerleri ise yüksek çıkmıştır. Bunun nedeni alt başarı grubundaki bireylerin büyük bir kısmının (\%96) kesme puanı olan 553'ün altında puan almış olmalarındandır. Bu durumda alt başarı grubu için modelden elde edilen doğru sınıflama oranının diğer gruplara göre yüksek olmasının nedeni olarak alt grup için oluşturulan modelde sinıflama sürecinde meydana gelen tesadüfi hataların fazla olması gösterilebilir. Bu sonuç alt grup ülkelerin veri yapısından kaynaklanmaktadır. Böylece; alt başarı grubu ülkeler için elde edilen lojistik regresyon veri madenciliği sınıflama modellerinin zayıf modeller olduğu söylenebilir. Diğer yandan Türkiye ve orta başarı grubunda kappa katsayısının kayda değer, üst başarı grubu ve çalışma örnekleminde orta düzey olduğu görülmektedir. 
Tablo 4. Okuduğunu Anlama Başarısını Yordamaya İlişkin Performans Kriterleri

\begin{tabular}{|c|c|c|c|c|c|c|c|c|c|}
\hline & & & \multicolumn{4}{|c|}{ Mutlak Performans kriterleri } & \multicolumn{3}{|c|}{ Bağıl Performans kriterleri } \\
\hline & Değişken & Veri & DSO & Roc alanı & HKOK & $\mathrm{OMH}$ & Kappa & GHKK & GMH \\
\hline \multirow{9}{*}{ 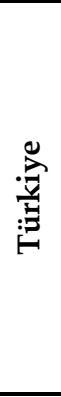 } & Tüm & Eğitim Verisi & 86,324 & 0,848 & 0,314 & 0,196 & 0,353 & 86,307 & 74,126 \\
\hline & Değişkenler & Geçerlik Verisi & 86,149 & 0,842 & 0,316 & 0,198 & 0,342 & 86,942 & 74,614 \\
\hline & $(34)$ & Test verisi & 85,377 & 0,835 & 0,322 & 0,200 & 0,328 & 87,113 & 74,738 \\
\hline & Seçilen & Ĕgitim Verisi & 85,741 & 0,812 & 0,325 & 0,211 & 0,271 & 89,428 & 79,805 \\
\hline & değişkenler & Geçerlik Verisi & 85,741 & 0,810 & 0,326 & 0,212 & 0,273 & 89,626 & 79,968 \\
\hline & (10) & Test verisi & 85,248 & 0,802 & 0,332 & 0,214 & 0,262 & 89,913 & 80,225 \\
\hline & Önemli & Ĕgitim Verisi & 85,034 & 0,810 & 0,333 & 0,215 & 0,255 & 90,185 & 80,480 \\
\hline & değişkenler & Geçerlik Verisi & 85,551 & 0,809 & 0,327 & 0,213 & 0,263 & 89,806 & 80,317 \\
\hline & (5) & Test verisi & 85,034 & 0,801 & 0,333 & 0,215 & 0,255 & 90,185 & 80,480 \\
\hline \multirow{9}{*}{ 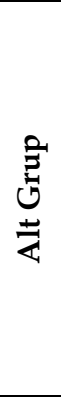 } & Tüm & Eğitim Verisi & 96,189 & 0,890 & 0,176 & 0,061 & 0,181 & 90,737 & 81,490 \\
\hline & Değişkenler & Geçerlik Verisi & 96,146 & 0,887 & 0,177 & 0,061 & 0,174 & 91,182 & 81,898 \\
\hline & (34) & Test verisi & 96,117 & 0,889 & 0,177 & 0,061 & 0,170 & 90,579 & 81,222 \\
\hline & Seçilen & Eğitim Verisi & 96,083 & 0,861 & 0,181 & 0,065 & 0,081 & 93,655 & 86,937 \\
\hline & değişkenler & Geçerlik Verisi & 96,095 & 0,856 & 0,182 & 0,065 & 0,088 & 93,841 & 87,232 \\
\hline & (10) & Test verisi & 96,013 & 0,871 & 0,182 & 0,065 & 0,055 & 92,885 & 86,297 \\
\hline & Önomli & Eğitim Verisi & 96,087 & 0,847 & 0,183 & 0,066 & 0,074 & 94,403 & 88,419 \\
\hline & değişkenler & Geçerlik Verisi & 96,083 & 0,846 & 0,183 & 0,066 & 0,070 & 94,476 & 88,494 \\
\hline & (8) & Test verisi & 95,990 & 0,854 & 0,183 & 0,066 & 0,040 & 93,836 & 87,777 \\
\hline \multirow{9}{*}{$\begin{array}{l}\text { Zn } \\
0 \\
\tilde{J} \\
0 \\
0\end{array}$} & Tüm & Eğitim Verisi & 85,796 & 0,853 & 0,320 & 0,204 & 0,390 & 84,989 & 71,399 \\
\hline & Değişkenler & Geçerlik Verisi & 85,693 & 8,851 & 0,320 & 0,204 & 0,386 & 85,191 & 72,103 \\
\hline & (34) & Test verisi & 85,423 & 0,852 & 0,323 & 0,205 & 0,372 & 85,246 & 72,130 \\
\hline & Seçilen & Eğitim Verisi & 84,754 & 0,825 & 0,331 & 0,219 & 0,314 & 88,090 & 77,379 \\
\hline & değişkenler & Geçerlik Verisi & 84,721 & 0,824 & 0,332 & 0,219 & 0,312 & 88,149 & 77,426 \\
\hline & (10) & Test verisi & 84,391 & 8,823 & 0,335 & 0,220 & 0,296 & 88,377 & 77,392 \\
\hline & Önemli & Eğitim Verisi & 84,759 & 0,823 & 0,332 & 0,220 & 0,312 & 88,195 & 77,611 \\
\hline & değişkenler & Geçerlik Verisi & 84,775 & 0,822 & 0,332 & 0,220 & 0,312 & 88,227 & 77,639 \\
\hline & (6) & Test verisi & 84,454 & 0,822 & 0,335 & 0,220 & 0,298 & 88,317 & 77,515 \\
\hline \multirow{9}{*}{ 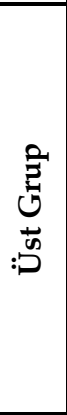 } & Tüm & Eğitim Verisi & 78,384 & 0,840 & 0,384 & 0,294 & 0,472 & 82,528 & 67,845 \\
\hline & Değişkenler & Geçerlik Verisi & 78,324 & 0,838 & 0,385 & 0,295 & 0,471 & 82,745 & 68,017 \\
\hline & (34) & Test verisi & 78,412 & 0,836 & 0,385 & 0,296 & 0,474 & 82,885 & 68,268 \\
\hline & Seçilen & Eğitim Verisi & 76,984 & 0,817 & 0,395 & 0,313 & 0,432 & 84,996 & 72,149 \\
\hline & değişkenler & Geçerlik Verisi & 76,996 & 0,817 & 0,396 & 0,313 & 0,432 & 85,070 & 72,209 \\
\hline & (10) & Test verisi & 77,010 & 0,815 & 0,397 & 0,314 & 0,435 & 85,358 & 72,492 \\
\hline & Önemli & Eğitim Verisi & 76,694 & 0,814 & 0,397 & 0,316 & 0,424 & 85,420 & 72,864 \\
\hline & değişkenler & Geçerlik Verisi & 76,694 & 0,813 & 0,398 & 0,316 & 0,424 & 85,465 & 72,899 \\
\hline & (6) & Test verisi & 76,602 & 0,811 & 0,399 & 0,317 & 0,425 & 85,824 & 76,602 \\
\hline \multirow{9}{*}{ 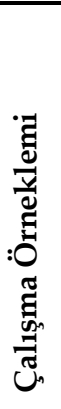 } & Tüm & Eğitim Verisi & 87,333 & 0,877 & 0,301 & 0,180 & 0,419 & 83,150 & 68,530 \\
\hline & Değişkenler & Geçerlik Verisi & 87,320 & 0,877 & 0,302 & 0,180 & 0,418 & 83,228 & 68,588 \\
\hline & (34) & Test verisi & 87,173 & 0,877 & 0,302 & 0,181 & 0,415 & 83,325 & 68,826 \\
\hline & Seçilen & Eğitim Verisi & 86,449 & 0,858 & 0,311 & 0,192 & 0,359 & 85,834 & 73,105 \\
\hline & değişkenler & Geçerlik Verisi & 86,457 & 0,857 & 0,311 & 0,192 & 0,359 & 85,854 & 73,121 \\
\hline & (10) & Test verisi & 86,312 & 0,858 & 0,312 & 0,193 & 0,355 & 86,000 & 73,371 \\
\hline & Önemli & Eğitim Verisi & 85,726 & 0,836 & 0,320 & 0,203 & 0,299 & 88,223 & 77,308 \\
\hline & değişkenler & Geçerlik Verisi & 85,739 & 0,836 & 0,320 & 0.203 & 0,299 & 88,233 & 77,316 \\
\hline & (5) & Test verisi & 85,587 & 0,838 & 0,320 & 0,204 & 0,290 & 88,315 & 77,474 \\
\hline
\end{tabular}

Not : DSO (Doğru sınıflama oranı), HKOK (Hata kareler ortalamasının karekökü), OMH (Ortalama mutlak hata), GHKK (Göreceli hata karelerinin karekökü), GMH (Göreceli mutlak hata) 
Tablo 4'deki diğer bir bulgu ise; üst başarı grubu ülkeler için kappa uyum katsayısının diğer gruplara göre daha yüksek çıkmasıdır. Bu anlamda üst başarı grubu ülkeler için oluşturulan model ile sınıflama sürecinde karışan tesadüfi hataların az olduğu söylenebilir. Bunun nedeninin üst başarı grubunda başarılı ve başarısız bireylerin oranının dengeli olmasından kaynaklı olduğu düşünülebilir. Bu durumda lojistik regresyon analizinde en yüksek doğru sınıflama performansına sahip alt başarı grubu ülkeler olmasına karşın, kappa katsayısı, GMH (göreli mutlak hata) ve GHKK (göreli hata karelerinin karekökü) ölçüleri bakımından en iyi sınıflama modelinin üst başarı grubu ülkeler için elde edildiği söylenebilir. Ayrıca kullanılan modelin başarılı olan öğrencilerle başarılı olmayan öğrencileri ayırma yeteneği bakımından Roc alanı değerleri incelendiğinde grupların tamamında 0,80 'in üzerinde olduğu için iyi düzeyde olduğu söylenebilir. Ancak alt başarı grubunun kappa istatistiğinin kabul edilebilir düzeyde çıkmamasına dayanarak kurulan modelin alt grup hariç tüm gruplarda amaca hizmet ettiği söylenebilir.

\section{Tartışma, Sonuç ve Öneriler}

Farklı başarı düzeyindeki gruplar için PISA 2018 okuduğunu anlama başarısını etkileyen değişkenlerin veri madenciliği ile belirlenmesine yönelik çalışmada, PISA testinin zorluk algısı, ebeveynlerin en yüksek mesleki statüsü ve evdeki eğitimsel eşyalar değişkenleri Türkiye, alt, orta, üst başarı grubu ve çalışma örnekleminde okuduğunu anlama başarısını etkileyen önemli ortak değişkenlerdir. Bu değişkenlerden PISA testinin zorluk algısı orta ve üst başarı grubu ülkelerde, ebeveynlerin en yüksek mesleki statüsü alt başarı grubu ülkelerde, evdeki eğitimsel eşyalar çalışma örnekleminde okuduğunu anlama başarısını etkileyen önemli değişkenlerin ilk sırasında yer almaktadır. Alanyazında mesleki statüsü yüksek ebeveynlere sahip olan öğrencilerin okuduğunu anlama becerisinin daha yüksek olduğuna yönelik araştırmalar (Vilenius-Tuohimaa ve ark., 2008; Gülleroğlu ve ark., 2014; Urfalı Dadandı ve ark., 2018) bu araştırmadaki sonucu desteklemektedir. Buna ek olarak; öğrencinin evdeki çalışma odası ve çalışma masası gibi ders çalışma ortamıyla ilgili evdeki eğitimsel eşyaların okuma başarısını artırdığına yönelik (Güzle Kayır, 2012) araştırma bulguları bu araştırmanın sonuçları ile tutarlıdır.

Okuma keyfi ise çalışma örneklemi hariç araştırma kapsamındaki diğer grupların tümünde önemli ortak yordayıcı değişken olarak belirlenmiştir. Bu değişken özellikle Türkiye için ilk sırada önemli değişkendir. Tavşancıl ve arkadaşları (2019) tarafından yapılan araştırmada okuma keyfi değişkeninin PISA okuduğunu anlama başarısını önemli ölçüde etkilediğine yönelik bulgular bu araştırma sonuçları ile uyumludur. Öğrenciden beklenen mesleki statü değişkeni Türkiye, orta ve üst başarı grubu ülkelerde önemli yordayıcı olarak görülmektedir. Aksu'nun (2018) PISA 2015 fen okuryazarlığı başarısını tahmin etmede öğrenciden beklenen mesleki statü değişkeninin en iyi yordayıcı değişkenlerden olduğuna ilişin bulgusu bu araştırmanın bulgusuyla paralellik göstermektedir. Bilgi iletişim teknolojileri (BİT) kaynakları alt ve orta başarı grubu ülkelerde önemli ortak yordayıcı olarak saptanması; Urfalı Dadandı ve arkadaşları (2018) tarafından yapılan araştırmada BİT kaynaklarının okuduğunu anlama başarısını anlamlı düzeyde yordamasına yönelik elde edilen bulgu ile uyumludur. Anne eğitim düzeyi değişkeni alt başarı grubu ve PISA uygulama örnekleminde önemli yordayıcı değişken olarak bulunmuştur. Diğer yandan baba eğitim düzeyi ise sadece alt başarı grubu ülkelerde önemli yordayıcı değişken olarak saptanmıştır. Bu sonuçlar (Urfalı Dadandı ve ark., 2018) tarafından yapılan çalışmada anne ve baba eğitim düzeyinin PISA okuduğunu anlama başarısını anlamlı düzeyde yordamasına ilişkin bulgu ile tutarlı olduğu belirlenmiştir. Okuma 
kavramı yetkinlik algısı üst başarı grubu ve çalışma örnekleminde önemli yordayıcı iken okuma kavramı zorluk algısı sadece alt başarı grubu ülkelerde önemli olarak saptanmıştır.

Özetle, bulgular PISA testinin zorluk algısı, ebeveynlerin en yüksek mesleki statüsü ve evdeki eğitimsel eşyalar değişkenlerinin grupların tamamında için PISA okuduğunu anlama başarısını önemli ölçüde etkilediğini göstermektedir. Dolayısıyla PISA testine yönelik zorluk algısı olan, mesleki statüsü düşük ebeveynlere sahip, evdeki eğitimsel eşyaları yetersiz olan öğrencilerin PISA okuduğunu anlama başarısı bakımından başarısız olacakları düşünülebilir. $\mathrm{Bu}$ sorunun önüne geçmek için uygun eğitim politikaları sorunlara müdahale ederek bu değişkenlere yönelik farklılıkların yol açtı̆̆ı olumsuzlukların giderilmesi mümkündür.

Yapılan araştırmada kullanılan lojistik regresyon modelinin sınıflama performansının kabul edilebilir düzeyde olduğu görülmüştür. Ayrıntılı incelendiğinde modelin sınıflama performansının gruplara göre farklılık gösterdiği belirlenmiştir. Grupların sınıflama performansının en yüksek olandan en düşük olana doğru sırası; alt başarı grubu ülkeler, çalışma örneklemi, Türkiye, orta ve üst başarı grubu ülkeler biçimindedir. Ancak alt başarı grubu ülkelerde kappa katsayısının düşük çıkması modelin sınıflama performansının yüksek çıkmasına gölge düşürmektedir. Bunun nedeni olarak alt başarı grubunda puanların kesme puanının altına yığılması nedeniyle puanlar dağılımının çarpık olmasından kaynaklı olduğu düşünülebilir. Sonuç olarak doğru sınıflama oranı, Roc alanı ve kappa katsayısı bakımından en iyi sonuçlar çalışma örneklemi üzerinde yapılan analizden elde edilmiştir. Bunun nedeni olarak örneklem hacminin geniş olması nedeniyle puanların kesme puanı etrafında dengeli dağılması düşünülebilir. Diğer yandan modelde kullanılan verilerin eğitim verisi, çapraz geçerlik verisi ve test verisi olarak ayrıldığı durumda model performansının önemsiz düzeyde azaldığı belirlenmiştir. Böylece modelin tahmin performansının ve sınıflama performansının iyi düzeyde olduğu söylenebilir. En önemlisi ise model performansının değişken sayısının azalmasından önemli düzeyde etkilenmemesi bulgusudur. Bu sonuca dayalı olarak daha az sayıda değişken ile öğrencilerin PISA okuduğunu anlama başarısını yordamanın mümkün olduğu söylenebilir.

Lojistik regresyon modeli ile Türkiye, alt, orta, üst başarı grubu ve çalışma örneklemi için yapılan araştırmada daha az sayıda değişken ile öğrencilerin PISA okuduğunu anlama başarısının iyi derecede yordanması, bu ülkelerdeki karar alıcıların eğitim politikalarına yön verirken PISA okuduğunu anlama başarısını olumlu etkileyen faktörlere daha fazla önem vermesiyle başarı artırılabilir.

Sonraki araştırmalar için ise şu öneriler sunulabilir:

1- Araştırmada kullanılan PISA okuduğunu anlama başarısı üç veya daha fazla kategoriye ayrılarak PISA okuduğunu anlama başarısını etkileyen değişkenlerin iki kategorili olduğu durumdaki etkili değişkenlere göre farklılık gösterip göstermediği incelenebilir.

2- Ayrıca kullanılan modelin PISA okuduğunu anlama başarısına yönelik sınıflama performansının PISA okuduğunu anlama başarısının üç veya daha fazla kategoriye ayrıldığında iki kategorili olduğu durumdaki sınıflama performansına göre farklılık gösterip göstermeyeceği incelenebilir.

\section{Teşekkür ve Bilgilendirme}

Bu çalışma “Farklı Başarı Düzeyleri İçin PISA 2018 Okuduğunu Anlama Başarısını Etkileyen Değişkenlerin Veri Madenciliği İle Belirlenmesi" adlı doktora tezinin bir parçasıdır. 


\section{Kaynakça}

Abad, F. M., \& Lopez, A. C. (2016). Data-mining techniques in detecting factors linked to academic achievement. Article in School Effectiveness and School Improvement, 28 (1), 39-55.

Abad, F.M., Gamazo, A., \& Rodriguez Conde, M.J. (2020). Educational Data Mining: Identification of factors associated with school effectiveness in PISA assessment. Studies in Educational Evaluation 66,100875 .

Abdous, M., He, W., \& Yen, C. J. (2012). Using data mining for predicting relationships between online question theme and final grade. Journal of Educational Technology \& Society, 15 (3), 77-88.

Akgöbek, Ö., \& Çakır, F. (2009).Veri Madenciliğinde Bir Uzman Sistem Tasarımı. Akademik Bilişim'09 XI. Akademik Bilişim Konferansı Bildirileri 11-13 Şubat 2009 Harran Üniversitesi, Şanlıurfa

Akkurt, Z., \& Karabağ Köse, E. (2019). Öğrenci başarısının okul, öğretmen ve aileyle ilgili değişkenler açısından incelenmesi. Pamukkale Üniversitesi Eğitim Fakültesi Dergisi, 47, 1-16.

Aksoy, E. (2014). Matematik alanında üstün yetenekli ve zekâlı öğrencilerin bazı değişkenler Açısından veri madenciliği ile belirlenmesi. (Yüksek Lisans Tezi). Ege Üniversitesi Eğitim Bilimleri Enstitüsü, İzmir.

Aksu, G., \& Güzeller, C.O. (2016).Classification of PISA 2012 mathematical literacy scores using decision-tree method: Turkey sampling. Education and Science 41(185), 101-122.

Aksu, G., \& Doğan, N. (2018).Veri madenciliğinde kullanılan öğrenme yöntemlerinin farklı koşullar altında karşılaştırılması. Ankara Üniversitesi Ĕ̆itim Bilimleri Fakültesi Dergisi, 51(3), 71-100.

Albayrak, A.S., \& Yılmaz, Ş. K. (2009).Veri madenciliği: Karar ağacı algoritmaları ve İMKB verileri üzerine bir uygulama. S.D.Ü. İktisadi ve İdari Bilimler Fakültesi Dergisi, 14(1), 31-52.

Berberoğlu, G., Çalışkan, M., \& Karslı, N. (2017). PISA 2015 sonuçlarına göre Türk öğrencilerinin ulaştığ düşünme süreçleri ve bu süreçlerle ilişkili olan değişkenler. Working Paper, August 2017

Bezek Güze, Ö., Kayri, M., \& Erdoğan, F. (2020).Analysis of factors effecting PISA 2015 mathematics literacy via educational data mining. Education and Science 45(202), 393-415.

Büyükkıdık, C., \& Mutluer, S. (2017). PISA 2012 verilerine göre matematik okuryazarlığının lojistik regresyon ile kestirilmesi. Marmara Üniversitesi Atatürk Eğitim Fakültesi Eğitim Bilimleri Dergisi, 46, 97-112.

Büyüköztürk, Ş., Kılıç Çakmak, E., Akgün, Ö. E., Karadeniz, Ş., \& Demirel, F. (2018). Bilimsel Araştırma Yöntemleri. Ankara: Pegem Yayıncilık.

Collet, D. (2003).Modelling Binary Data., Chapman \& Hall, Florida

Coşkuner, T. (2013). Uluslararası öğrenci başarı değerlendirme programı (PISA) 2009 uygulaması okuma becerileri okuryazarlı̆̆ı'nı etkileyen faktörler. (Yayınlanmamış Yüksek Lisans Tezi). Akdeniz Üniversitesi Eğitim Bilimleri Enstitüsü, Antalya.

Field, A. (2009). Discovering Statistics using SPSS. London: Sage.

Gamazo, A., \& Abad, F. M.(2020).An exploration of factors linked to academic performance in PISA 2018 through data mining techniques. Journal Frontiers in Psycholog, 11:575167

Gülleroğlu, H. D., Bilican Demir, S. B., \& Demirtaşlı, N. (2014). Türk öğrencilerinin PISA 2003-2006-2009 dönemlerindeki okuma becerilerini yordayan sosyoekonomik ve kültürel değişkenlerin araştırılması. Eğitim Bilimleri Fakültesi Dergisi, 47(2), 201-221.

Güzle Kayır, Ç. (2012). PISA 2009 Türkiye verilerine dayanarak okuma becerileri alanında başarılı okullar ile başarısız okulları ayırt eden okul içi etmenler ve sosyo-ekonomik faktörler.(Yayınlanmış Yüksek lisans tezi). Akdeniz Üniversitesi Sosyal Bilimler Enstitüsü, Antalya. 
Ho Yu, C., Kaprolet, C., Jannasch Pennell, A., \& Digangi, S. (2012). 'A data mining approach to comparing american and canadian grade 10 students' PISA science test performance. Journal of Data Science 10, 441-464.

Hosmer, D.W., \& Lemeshow, S. (2000). Applied lojistic regression. John WileySons, Inc : Canada. http://books.google.com.tr/ adresinden edinilmiştir.

İnan, O. (2003). Öğrenci işleri veri tabanı üzerinde veri madenciliği uygulamaları. (Yüksek Lisans Tezi). Selçuklu Üniversitesi Fen Bilimleri Enstitüsü, Konya.

Kiray, S.A., Gok, B., \& Bozkir, A.S. (2015). Identifying the factors affecting science and mathematics achievement using data mining methods. Journal of Education in Science, Environment and Health (JESEH), 1(1), 28-48.

MEB (2019). PISA 2015 ulusal ön raporu. Ankara: Meb.

OECD (2019). PISA 2018 assessment and analytical framework. Paris: OECD Publishing.

Özer Özkan, Y., \& Acar Güvendir, M. (2014).Socioeconomic factors of students' relation to mathematic achievement: comparison of pisa and öbbs. International Online Journal of Educational Sciences, 6 (3), 776-789.

Önder, R., Gelbal, S. (2016). PISA 2012 sonuçlarına göre matematik öz-yeterlik ve kaygı puanlarının bazı değişkenlere göre incelenmesi. Eğitim ve Öğretim Araştırmaları Dergisi 5(3),271-278.

Özarslan, S. (2014). Öğrenci performansının veri madenciliği yöntemleri ile belirlenmesi. (Yayınlanmamış Yüksek Lisans Tezi).Kırıkkale Üniversitesi Fen Bilimleri Enstitüsü, Kırıkkale.

Tatlıdil, H. (1992). Uygulamalı çok değişkenli istatistiksel analiz. Ankara: Engin Yayınları.

Tavşancıl, E., Yıldırım, Ö., \& Bilican Demir, S. (2019).Direct and indirect effects of learning strategies and reading enjoyment on PISA 2009 reading performance. Eurasian Journal of Educational Research, 82, 169-190.

Tabachnick, B. G., \& Fidell, L. S. (2007). Using multivariate statistics. Boston: Pearson/Allyn \& Bacon.

Urfalı Dadandı, P., Dadandı, İ., \&Koca, F. (2018). PISA 2015 Türkiye sonuçlarına göre sosyoekonomik faktörler ile okuma becerileri arasındaki ilişkiler. Uluslararası Türkçe Edebiyat Kültür Eğitim Dergisi, $7(2), 1239-1252$.

Uyulgan, M. A., \&Akkuzu, N. (2017).Ortaöğretim öğrencilerinin akademik başarılarını yordayan kişisel faktörler üzerine bir araştırma. Bartın Üniversitesi Ĕ̆itim Fakültesi Dergisi, 6( 3), 1211-1226.

Vilenius Tuohimaa, P. M., Aunola, K., \&Nurmi, J. E. (2008). The association between mathematical word problems and reading comprehension. Educational Psychology, 28(4), 409-426.

Yıldırım, Ö. (2012). Okuduğunu anlama başarısıyla ilişkili faktörlerin aşamalı doğrusal modellemeyle belirlenmesi (PISA 2009 Hollanda, Kore ve Türkiye karşılaştırması). (Yayınlanmış Doktora Tezi).Ankara Üniversitesi Eğitim Bilimleri Enstitüsü Ankara.

Yue, Y. (2021). The prediction model of college english performance based on data mining under the concept of obe. Engineering Intelligent Systems, 2,89-96.

Yung, J. L., Hsu, Y. C., \& Rice, K. (2012). Integrating data mining in program evaluation of k-12 online education. Journal of Educational Technology \& Society, 15 (3), 27-41.

Wu, M., \& Adams, R.J. (2002). Plausible Values - Why They Are Important. International Objective Measurement Workshop, New Orleans. 